\title{
Tecnocracia ou Tecnoassessoria?
}

Carlos Estevam Martins*

1. Politica e Sociedade. 2. Os Tecnólogos na Sociedade. 3. Os Tecnólogos na Politica.

A tese de que os governos modernos tendem, cada vez mais, a se transformar em governos de tipo tecnocrático vem sendo proposta com crescente insistência na literatura política contemporânea. Há, naturalmente, os que combatem e os que defendem a tecnocracia. Mas isso muito raramente quer dizer que existam discordâncias quanto ao advento, o poder expansivo e a própria inevitabilidade do fenômeno. Ao contrário, as divergências tendem a se concentrar na discussão sôbre os custos e benefícios acarretados pelo processo de tecnocratização. De que tal processo se encontra em marcha parece não haver maiores dúvidas. ${ }^{1}$

O principal objetivo dêste artigo é o de reabrir questões que desfazem êsse aparente ponto pacífico. A nosso ver, ainda não se tornou de todo descabido formular perguntas do seguinte teor: até que ponto não estaremos tomando a simples propagação das ideologias tecnocráticas pelo avanço da tecnocracia

* Professor-contratado do Departamento de Ciencias Sociais da Escola de Administração de Emprêsas de São Paulo, da Fundação Getúlio Vargas. I Mello e SouzA, Nelson. Tecnocracia e Nacionalismo. Revista de Administração Pública, n², 1967.

R. Adm. Emp., Rio de Janeiro, 10(2): 39-66, jul./set. 1970 
em pessoa? Que condições, a rigor, precisam ser satisfeitas para que os sistemas políticos se transformem no sentido previsto pelos prognósticos tecnocráticos? Até que ponto as evidências empíricas utilizadas para substanciar as hipóteses tecnocráticas não têm sido forçadas a ser mais eloquientes do que na realidade elas são ou podem ser?

De certo modo, o presente artigo pode ser descrito como uma tentativa de sugerir dificuldades comumente negligenciadas nos estudos sôbre tecnocracia. Há quem pense que é muito difícil ou, talvez, pràticamente impossível a construção de uma demonstração aceitável da teoria tecnocrática. Outros não só julgam fácil a tarefa como acreditam que a realizaram. Como as provas oferecidas podem ser tidas como mais ou menos convincentes em função dos critérios de aceitação que adotamos, seria proveitoso retomar a questão, reformulando-a a partir de um ponto de vista mais exigente.

\section{Política e Sociedade}

Em geral, é muito difícil descobrir a que tipo de situação os cientistas sociais estão se referindo quando usam o têrmo tecnocracia. Os dicionários fornecem uma definição aparentemente satisfatória, pois limitam-se a mencionar a existência de uma "situação na qual o poder efetivo pertence a técnicos denominados tecnocratas". Na linguagem comum, entretanto, do mesmo modo que na literatura especializada, uma boa parte da notoriedade do têrmo deve-se justamente à falta de precisão com que costuma ser utilizado.

$A$ ambigüidade do que se entende por tecnocracia tem permitido, entre outras coisas, encobrir a necessidade de se estabelecer uma linha divisória bem demarcada entre duas temáticas que nas discussões sôbre os regimes tecnocráticos aparecem indistintamente mescladas: na verdade, existe, de um lado, uma temática sócio-econômica; de outro, uma temática política. A especificidade da primeira aparece claramente em expressões como as seguintes: recursos humanos altamente qualificados, profissionais, cérebros, talentos especializados, comunidade técnico-científica, tecnólogos, sistema social da ciência e outras tantas que fazem exclusiva referência à esfera sócio-econômi- 
ca da vida social. O mesmo, entretanto, não acontece com o têrmo tecnocrata: êle é indistintamente usado tanto com referência à dimensão vertical relativa às hierarquias de poder, quanto com referência à dimensão horizontal relativa aos processos de divisão do trabalho, diferenciação de papéis, alocação de status e estruturação de carreiras.

Como passo inicial, é indispensável sublinhar tanto a existência, quanto a importância da distinção entre as duas temáticas. Tecnocratas e tecnocracia, por um lado; tecnólogos e tecnoassessoria, por outro, são fenômenos que se referem a dimensões distintas da realidade social. Os tecnólogos fazem parte dos recursos humanos disponíveis numa dada sociedade. Na medida em que êsse tipo específico de mão-de-obra é recrutado, coordenado e pôsto a funcionar a serviço das grandes organizações públicas e privadas, conviria dizer, para assinalar êsse fato, que tais organizações se apóiam em staffs técnicos ou tecnoassessorias. Quando falamos, entretanto, de tecnocratas e tecnocracias temos em mente um fenômeno de outra ordem. Nesse caso, não estamos referindo-nos pura e simplesmente à existencia de uma elite técnico-científica pois, na verdade, o que queremos dizer é que os tecnólogos podem ser algo mais do que meros tecnólogos e que a elite técnico-científica se converteu, ou pode vir a converter-se, numa elite de poder.

Convém, portanto, como se fará ao longo dêste artigo, examinar em separado as duas ordens de fenômenos: os tecnólogos na sociedade e os tecnólogos na política.

\section{Os Tecnólogos na Sociedade}

2.1. Os tecnólogos, embora não necessàriamente os tecnocratas, ocupam um lugar de destaque na literatura sôbre desenvolvimento econômico e sôbre sociedades industriais avançadas. Pràticamente sem exceção, os estudiosos dos processos de modernização têm insistido sôbre a crescente importância da posição conquistada pelo setor profissional na estrutura ocupacional das sociedades modernas, assim como sôbre a natureza estratégica da contribuição técnico-científica para a dinâmica do processo de desenvolvimento. De um modo geral, parece não haver objeções notáveis à crença de que as variaçóes expe- 
rimentadas pelo estoque de tecnólogos de uma dada sociedade são altamente conseqüentes para a consecução de um grande número de objetivos básicos do sistema.

As principais componentes do que hoje se descreve como "processo geral de profissionalização" ${ }^{2}$ começaram a configurar-se a partir do século XIX, concomitantemente à expansão do industrialismo, relação essa que foi sintetizada na famosa equação de W. J. Goode: "uma sociedade industrializante é uma sociedade profissionalizante". De fato, a estreita conexão entre os dois fenômenos tem sido amplamente atestada ao nível das evidências empíricas. Um indicador expressivo, por exemplo, é a elevada concentração de competência técnico-científica que se observa nos países altamente modernizados. Assim é que, apenas cinco países (Estados Unidos, União Soviética, Inglaterra, Alemanha e França) empregam atualmente cêrca de $80 \%$ de todos os pesquisadores de alto nível existentes no mundo. ${ }^{3}$

Os dados obtidos por meio de comparações diacrônicas não são menos expressivos. Contrastando o período compreendido pelos últimos setenta anos com todo o resto do passado histórico, Dereck Price estimou que os cientistas atualmente vivos constituem cêrca de $90 \%$ de todos os que já existiram. ${ }^{4}$

Contudo, dizer que a modernização depende do desenvolvimento das profissões é contar apenas o comêço da história. Na verdade, tão importante quanto a conexão entre os dois fenômenos, é o fato de que a própria natureza da ırelação que os une variou com a passagem do tempo. Uma variação acentuadamente a favor da tecnologia. Seja qual fôr a importância que tenha tido em períodos anteriores, o fato é que o elemento técnicocientífico passou a assumir, durante as três ou quatro últimas décadas, uma posição cada vez mais saliente nas estruturas informacionais em que se apóiam as modernas organizações econômicas e governamentais. Tal mudança, dada a magnitude e a multiplicidade de suas consequiências, constitui um aspecto essencial do que se convencionou chamar de Revolução Tecnológica.

2 Em Wollmer e Mills (ed.) Professionalization. Prentice-Hall, 1966.

3 Adams, Walter (ed.). The Brain Drain. The Macmillan Company, 1968.

4 Em Chorafas, D. N.. The Knowledge Revolution. George Allen e Unwin, 1968. 
O núcleo dêsse desenvolvimento foi descrito por Galbraith ${ }^{5} \mathrm{em}$ têrmos de três mudanças fundamentais: 1 . ao nível dos processos produtivos, surgiu uma tecnologia hiperanalítica em substituição à preexistente tecnologia de agregados; 2 . ao nível das relações interorganizacionais instituiu-se a prática do planejamento em substituição aos mecanismos automáticos do mercado; 3. ao nível das relações intra-organizacionais, multiplicaram-se os orgãos decisórios coletivos em substituição à gestão empresarial clássica.

Essas três linhas evolutivas têm como denominador comum o fato de que atividades intelectualmente pouco exigentes foram substituídas por formas alternativas que demandam alto grau de competência especializada. As organizações anteriores à Revolução Tecnológica, dirigidas por empresários individuais, utilizando tecnologia menos avançada e operando em resposta aos estímulos do mercado, podiam dar-se ao luxo de manter relações vagas e defasadas com o que se passava no interior das instituições de pesquisa. Isso, na verdade, não lhes trazia maiores inconvenientes, uma vez que a maior parte das informações em que baseavam seus cálculos e decisões podia certamente ser obtida por métodos muito menos sofisticados.

Ao contrário de suas predecessoras, que consumiam, em larga medida, conhecimentos intuitivamente improvisados, oriundos da experiência própria ou simplesmente tomados de empréstimo, as organizações tecnològicamente revolucionadas tornaramse, em sentido rigoroso, science-based organizations, tão crucial passou a ser para elas o insumo específico representado pelo conhecimento técnico-científico. Os talentos especializados deixaram de ser peças acessórias mais ou menos dispensáveis. As grandes organizaçóes modernas são tão mais modernas quanto mais se fundam sôbre tecnoassessorias bem estabelecidas e ubíquas. Há até mesmo quem chegue a predizer, como Stinchcombe, que o resultado final da era tecnológica será uma sociedade em que "tôdas as organizações se transformarão em simples ramos ou modificações da universidade"."

5 Galbraitr. The New Industrial State. Hamish Hamilton, 1967.

- STINCHCOMBe. Organization. In Smelser. Sociology: an Introducion. 
2.2. Tais processos, ocorridos ao nível da economia e da sociedade, constituem a base a partir da qual foram feitas inferências tecnocráticas para o plano político. Entretanto, caberia perguntar: admitindo-se que o ordenamento dos fatôres produtivos e as relações entre as organizações tendem a se alterar no sentido acima descrito, seria igualmente provável a expectativa de transformações analògicamente revolucionárias ao nível do sistema político? Teriam as novas realidades da vida moderna afetado em forma substancial o modo pelo qual as fôrças sociopolíticas se relacionam entre si e, em particular, o modo pelo qual o govêrno, como uma organização entre as outras, se desincumbe da tarefa de estabelecer decisóes autoritativamente válidas para a sociedade em seu conjunto?

Para certo grupo de autores, não há dúvida de que uma coisa leva necessàriamente à outra. Assim, a tecnocracia, como realidade distinta da tecnoassessoria, é vista por Geiger ${ }^{7}$ como sendo uma decorrência inevitável do processo de modernização: ela representa um desenvolvimento inescapável na evolução dos sistemas políticos modernos na medida em que reflete, no plano político, a nova estrutura de classes que tende a prevalecer nas sociedades industriais avançadas. Em sua forma mais genérica, - argumento enuncia uma relação de causalidade entre duas variáveis abstratas: contrôle sôbre um fator de poder (o saber especializado) produz poder de decisão na esfera política ou, em outras palavras, quanto mais importante fôr a participação dos tecnólogos para a consecução dos objetivos de uma dada coletividade, maior será sua participação na determinação dêsses objetivos e, portanto, mais tecnocrático o regime político correspondente. Em sua forma mais concreta, o argumento é visìvelmente neomarxista: com base no esquema, segundo o qual a classe dominante na sociedade civil detém em suas mãos as rédeas do govêrno, Geiger redefine a estrutura de classes de modo a caracterizar os tecnólogos como sucessores da burguesia e, daí, infere sua posição hegemônica nas estruturas de dominação.

O argumento economicista de Galbraith pertence ao mesmo gênero. Para êle não há dúvida a respeito do que concede poder

7 GeIGER. In: DAFRENDORF. Class and Class Conflict in Industrial Society. Stanford University Press, 1959. 
político a um determinado fator de produção ou àqueles que o controlam: "o poder vai para o fator que é mais difícil de obter ou substituir. Em linguagem precisa, adere àquele que possuir maior inelasticidade de oferta na margem". Assim, houve uma época em que os que controlavam a terra não tinham dificuldades em obter capital e mão-de-obra nas quantidades requeridas. $\mathrm{Na}$ época seguinte, a terra tornou-se um fator relativamente abundante e o contrôle do capital passou a ser o elemento decisivo na determinação da elite politicamente dominante. Atualmente, nas sociedades avançadas, o poder deslocou-se para os detentores de talento especializado: "dada uma organização competente, o capital hoje se acha fàcilmente disponivel. A mera posse do capital, contudo, não é mais uma garantia de que os talentos requeridos possam ser obtidos e organizados". Sem se importar aparentemente com o fato de que é precisamente nos países mais ricos e, dentro de cada país, nas organizações mais ricas, que se encontram as maiores concentrações de talento especializado, Galbraith conclui que, ao contrário das suposições correntes, o poder não passou para o fator trabalho, nem tão pouco e muito menos ficou com seus antigos detentores. Os operários não-qualificados, assim como os portadores de qualificações convencionais, estariam sofrendo, juntamente com os capitalistas, os efeitos da marginalização política decorrente da abundância de capital.

Uma forma alternativa de inferir senão a realidade mas, pelo menos a inevitabilidade da tecnocracia foi recentemente explorada por Wanderley dos Santos. ${ }^{8}$ Aqui, uma vez mais, aplica-se o mesmo método de predizer a tecnocratização do sistema político a partir da modernização tecnológica da sociedade. Por um lado, êle destaca o extraordinário crescimento da interdependência social que se observa no contexto das sociedades industriais. Esse princípio da crescente interdependência seria, segundo Mannheim, uma das tendências fundamentais das sociedades modernas e determinaria, como resultado, o alargamento da cadeia de conseqüências engendrada por cada ato individual. Por outro lado, Wanderley dos Santos salienta a importância da "explosão do conhecimento" e da institucionalização da ativi-

8 SAntos, Wanderley. Teoria Política e Prospectos Democráticos. Revista Dados, n 6, 1969. 
dade científica a qual deixou de ser um trabalho de amadores e se transformou num setor integrado da sociedade, organizado em bases profissionais. Dada a conjugação dêsses dois processos não se pode mais esperar que as elites políticas de hoje, assim como os vários segmentos da opinião pública, continuem tão capazes como o foram no passado, no que diz respeito ao conhecimento das cadeias de conseqüências que as decisões originam: "com a explosão do conhecimento e com a penetração da ciência sob forma tecnológica em quase todos os aspectos da vida humana, essa situação foi totalmente subvertida" ... "a elite teve que segregar, ou associar um nôvo tipo de homem social o especialista. Os especialistas são homens capazes de perceber a cadeia de consequiências de forma incomparàvelmente mais ampla do que qualquer outra pessoa". A seguir, supõe-se que o sistema político, em lugar de simplesmente se adaptar às novas condições emergentes, sofra um processo de substancial reestruturação. Seriam as seguintes as duas componentes principais do nôvo padrão de relações políticas: em primeiro lugar - govêrno se transformaria em sua própria essência, em conformidade com o espírito da ideologia tecnocrática, e passaria a operar como "uma agência para a produção de funções compatíveis tendo em mira o objetivo de manter no nível mais baixo possível os custos sociais acarretados pelas decisóes incorretas; em segundo lugar, "a feudalização do poder por uma elite de técnicos especializados" aparece como "o mais forte processo em operação na sociedade contemporânea".

2.3. Para resumir as páginas anteriores, é suficiente sublinhar dois pontos. $O$ primeiro diz respeito à inexistência de qualquer grau significativo de dissenso quanto à tese de que hoje os tecnólogos são mais importantes do que jamais o foram no passado. Em suma, não é isso que está em questão, uma vez que ninguém lança dúvidas contra a afirmação de que, nas sociedades industriais avançadas, os tecnólogos existem em maior número e diversidade, sãc mais úteis e utilizados, são mais prestigiados e, inclusive mais bem pagos.

O segundo ponto é que é controvertido, embora êle simplesmente enuncie que a comprovação do primeiro ponto não autoriza qualquer conclusão automática com respeito à questão de 
saber quem manda em quem nas sociedades que se modernizam em têrmos de absorção de ciência e tecnologia. Uma forma de ilustrar essa afirmação consiste em supor que os tipos de gestão podem ser analisados em função de duas dimensões distintas: a primeira delas poderia ser denominada processo de secularização, entendendo-se por êsse têrmo o grau em que as decisões tomadas se fundamentam em considerações de caráter técnicocientífico; a segunda dimensão seria o processo de tecnocratização, ou seja, o grau em que os tecnólogos (em contraste com os políticos, os burocratas, os capitalistas, os militares, os governos estrangeiros, os trabalhadores ou qualquer outro tipo de agente social) determinam os resultados a que chegam os processos de tomada de decisão. A utilização combinada dêsses dois critérios permitiria distinguir pelo menos quatro diferentes tipos de gestão:

TECNOCRATIZAÇÃO

\begin{tabular}{|c|c|c|}
\cline { 2 - 3 } & \multicolumn{2}{c|}{ SECULARIZAÇÃO } \\
\hline ALTA & BAIXA \\
\hline BAIXA & I & II \\
\hline
\end{tabular}

Entre outras coisas, o quadro acima sugere a idéia de que o avanço da tecnocratização pode vir acompanhado de um grau maior ou menor de secularização, da mesma forma que o progresso no sentido de uma secularização crescente pode ou não implicar num incremento proporcional do grau de tecnocratização. Em outras palavras, é possivel, em princípio, supor que os dois processos variem independentemente; e, até o momento em que se demonstre a existência de um tipo predominante de relação entre ambos, a razão metodológica não só aconselha como requer que se mantenha de pé a suposição da independência.

Os autores acima discutidos sustentam que o tipo I é muito mais provável que o tipo III, e com isso dão por solucionada tôda a complexa problemática política que tal postulação encerra mas não enfrenta. Se supusermos, entretanto, que as duas 
ocorrências são equi-prováveis ou, para extremar o argumento, que III ocorre com frequiência significativamente superior a I, teríamos hipóteses segundo as quais os tecnólogos não se tornam uma fôrça polìticamente dominante simplesmente pelo fato de que os seus serviços passaram a ser mais generalizada e intensivamente utilizados pelas fôrças que efetivamente disputam e controlam o poder. Se uma hipótese dessa natureza faz sentido, caberia perguntar: que outras coisas um tecnoassessor precisa ser para converter-se num tecnocrata pròpriamente dito? Além de uma certa soma de conhecimentos especializados, que outros recursos êle precisa acumular para se tornar um gladiaror vitorioso na arena política? Se, ao contrário do rei-filósofo, êle necessita conquistar o poder em lugar de ser simplesmente convidado a assumi-lo, como se explica que os interêsses que competem com os seus não tenham sido capazes de encontrar meios e modos de barrar-lhe o passo? $\mathrm{E}$ por falar em interêsses, teriam os tecnólogos algum tipo de interêsse que os unifique $\mathrm{e}$ os distinga como tais em oposição às outras escalas de preferências que se entrechocam na busca de implantação política adequada? São indagações dêsse gênero que nos levam a examinar a tese tecnocrática em têrmos de análise política pròpriamente dita. Trataremos, portanto, de encaminhar o leitor à consideração dêsse aspecto nas páginas subseqüentes.

\section{Os Tecnólogos na Política}

Para ingressarem na esfera política e converterem-se em tecnocratas de fato é forçoso que os tecnólogos sejam capazes de adquirir poder, e que isso seja feito por meio de competição vitoriosa contra as fôrças politicamente ativas que se empenham em impor sua vontade nos processos de tomada de decisão. Não levar em consideração êsse fator elementar da vida política $e$ supor os tecnólogos atuando num vácuo de poder, têm sido o pecado original de muitas análises sôbre o fenômeno tecnocrático. Sendo a tecnocracia um fenômeno político, é necessário que ela ocorra no contexto do sistema político e o que caracteriza a especificidade dêsse contexto é a disputa pelas vantagens e desvantagens associadas à posse e ao exercício do poder, bem como o fato de que as partes envolvidas em tais conflitos encontram-se desigualmente equipadas quanto aos meios de 
que dispõem para ascender às posições de poder ou influir sôbre aquêles que as controlam.

Uma abordagem dêsse tipo, que enfatiza a natureza conflitiva da vida política, assim como os recursos de pressão e contrôle mobilizados pelos interêsses em luta, suscita uma série de questões que ainda não foram convenientemente formuladas nos trabalhos que procuram acumular argumentos e evidências a favor da tese da tecnocratização crescente. $\mathrm{Na}$ realidade, os caminhos que os tecnólogos necessitam percorrer para avançar das zonas periféricas até as cercanias dos centros de poder parecem ser muito mais pontilhados de obstáculos e armadilhas do que até então tem sido suposto pelos proponentes de soluções tecnocráticas.

3.1. Como em geral se admite, o recurso político tìpicamente controlado pelos tecnocratas é o saber especializado. Assim sendo, um dos problemas cruciais para qualquer teoria tecnocrática deve ser $o$ de identificar as condições políticas que fortalecem a posição dos detentores dêsse recurso, em comparação com a daqueles que controlam outros tipos alternativos de fatôres de poder. Uma tentativa nessa direção foi recentemente feita por B. Lamounier com base na hipótese de que certas configuraçóes específicas do sistema político ofereceriam condições propícias à constituição de lideranças teconcráticas. $O$ contrôle sôbre o saber especializado poderia, assim, vir a se transformar num meio efetivo para a aquisição de poder político real, não em virtude da expansão do processo geral de secularização, mas devido ao modo pelo qual se articula o confronto entre as diferentes fôrças políticas em conflito. Conforme assinala $\mathrm{B}$. Lamounier, seria êsse, particularmente, o caso dos chamados sistemas de mobilização, os quais tenderiam a provocar uma acentuada dicotomia entre papéis instrumentais e papéis integradores: "o problema crucial é o da mobilização, vale dizer, a crescente exposição da população aos meios de comunicação de massa, a quebra de suas lealdades tradicionais e, em consequiência, sua crescente participação, o que, nesta fase, coloca agudamente o problema da identificação simbólica com a comunidade política, com suas organizações e com seus líderes de maior base popular. A atitude de uma elite tecnocrática pode ser a de cavalgar essa onda, pondo-se como símbolo único (Egi- 
to); ou de reprimi-la, exacerbando suas características instrumentais a fim de provocar a desmobilização. Tomando esta última alternativa, a tarefa é tornar cada vez menos interessante a política, tecnizando-a". ${ }^{\circ}$

A conclusão implicada por essa análise seria a de que o regime tecnocrático surge como alternativa a um sistema de mobilização. Em nenhum momento, entretanto, a análise especifica para quem tal alternativa se apresenta como preferivel, como tão pouco indica quem se incumbe de promovê-la. Em têrmos de poder, a suposição implícita parece ser a de que as fôrças políticas dominantes, uma vez confrontadas com a ameaça representada pela eclosão de um sistema de mobilização, confessam-se incapacitadas para conter o surto de participação e decidem optar pelo menor dos males, qual seja o de perder o poder para uma elite tecnocrática. Em outras palavras, ou o argumento supóe um processo de transferência de poder que destituiu os detentores de posiçб̃es de comando, ou então não se trata de um argumento tecnocrático.

Ao que tudo indica, estamos precisamente diante do segundo caso. Com efeito, o que dá a êsse argumento a aparência de tecnocrático, parece ser a confusão, bastante usual, entre dominação efetiva de certos setores da sociedade sôbre outros e estilo ou método de dominação. Como se sabe, as relaçóes de dominação política podem ser efetivadas por meio de diferentes métodos que incluem desde partidos políticos e sistemas eleitorais até o puro e simples recurso à violência física. Qualquer um dêsses métodos, ou qualquer combinação entre êles, define o estilo adotado pela elite dirigente no processo de impor sua vontade sôbre os interêsses que lhe são hosțis: todavia, seria descabido supor que a preferência por êste ou aquele método é suficiente para definir que setor, ou que coalização de setores, controla o processo decisório e consegue determinar o conteúdo das decisర̃es implementadas pelo sistema.

O método de tecnizar o processo decisório, ou de apresentá-lo como tal aos que a êle não têm acesso, não implica necessàriamente num incremento do grau de tecnocratização do sistema

- LAmounier. Exploraçб̃es sôbre Teoria da Liderança e Elites Tecnocráticas. Revista Dados, $\mathrm{n}^{\circ} 4,1968$. 
político. E claro que um regime verdadeiramente tecnocrático tenderia, mais do que qualquer outro, a lançar mão dêsse instrumento de contrôle social. Mas a recíproca não tem porque ser verdadeira. Em têrmos de poder e de políticas, a tecnização significa coisas diferentes no Peru, na União Soviética e na Indonésia, embora como formula política ela tenda a produzir em tôda parte os mesmos resultados desmobilizadores. A tecnização, reduzindo o escopo do conflito político, restringe o número de contedores legítimos e, nesse sentido, tende a ser incompatível, isto sim, com as formas democráticas ou populistas de organização da vida política. Mas a existência de um número mais restrito de participantes não comprova e, a rigor, nem sequer sugere que a relação de fôrças foi redefinida a favor de uma elite de especialistas. $O$ que a tecnização efetivamente manifesta é a necessidade experimentada por elites burocráticas, econômicas ou militares de usar os valores próprios à ideologia tecnocrática como instrumento de legitimação de posições politico-ideológicas que emanam de origens sociais específicas, entre as quais seguramente não se encontra a comunidade técnicocientífica. A expansão da ideologia tecnocrática certamente indica tecnocratização ao nível das comunicações simbólicas, mas não seria razoável concluir que os especialistas controlam as decisões só porque passamos a ouvir essa afirmação com mais insistência do que antes.

3.2. As transformações experimentadas nas pautas de recrutamento para posiçóes organizacionais de nivel superior constituem um outro tipo de evento que tem sido interpretado como eviđência da intervenção tecnocrática. De um modo geral, supõe-se que as agências governamentais não podem expandir impunemente as dimensóes de seus quađros técnico-científicos. $\mathrm{Na}$ medida em que se reestruturam para absorver um maior número de especialistas de alto nível, uma proporção corespondente de poder tenderia a ser realocada no sentido de fortalecer a capacidade de intervenção de staff técnico. Admite-se que, uma vez que foi recrutado para posições organizacionais de destaque, é inevitável que o especialista adquira a faculdade de decidir ou, pelo menos, de determinar de maneira preponderante as escolhas daqueles que, por delegação política, são os responsáveis oficiais pelas decisóes tomadas. Os titulares dos cargos 
de chefia ficariam assim reduzidos à simples condição de promatores da opinião tecnocrática junto aos diferentes públicos cuja adesão e apoio se trata de obter. Os dirigentes, ou seus equivalentes, teriam perdido seu antigo papel de compradores de idéias úteis para os seus próprios propósitos e se convertido em meros vendedores ou propagandistas de interêsses alheios. ${ }^{10}$

A reorganização tecnocratizante das estruturas de poder seria evidenciada por dados do seguinte tipo: no Partido Comunista da União Soviética, a proporção de membros da classe operária caiu de $60 \%$ ao tempo da Revolução para $32 \%$ em 1956. Tal queda se explica, em parte, pela ampliação da representação camponesa que passou de 6 para $17 \%$ no mesmo período. Mas - outro lado da medalha estaria no fato de que os tecnólogos passaram a ser $25 \%$ dos filiados, sendo que representavam um mero $1,8 \%$ da população total e apenas $4 \%$ da fôrça de trabalho. ${ }^{11}$

Nos -Estados Unidos, especialmente depois da Segunda Guerra, uma evolução similar parece ter ocorridơ. Como assinala Robert Gilpin, "os cientistas tornaram-se importantes para $\sigma$ governo não apenas como pesquisadores trabalhando em seus laboratóriòs: hoje êles são participantes efetivos do processo político nacional". Analisando as diferentes formas de atuação dos tecnólogos, Gilpin destaca: "participação como ativistas em várias associaçбes voluntárias; posições de assessoramento nos mais altos níveis do governo americano; formação de organizaçðes para ação política que pressionam com êxito a aprovação de leis pelo Congresso; participação nas negociações de acordos internacionais, assim como em debates televisionados sôbre questões básicas de política nacional". A ascensão dos tecnólogos na estrutura burocrática do Estado norte-americano é ilustrada por uma série de inovações administrativas cujo sentido geral é o de proporcionar acesso aos centros de decisão do sistema. $O$ processo que se iniciou nos anos da guerra com a criação do Office of Scientific Research and Development (OSRD) e que prosseguiu com a formação do General Advisory Committee (GAC) em 1946, atingiu seu pico em 1957 quando o GAC foi elevado

10 11
MeYnaud. La Tecnocracia: Mito o Realidad? Tecnos, 1968.

LENSKr. Power and Privilege. McGraw-Hill, 1966. 
ao nível da Casa Branca para atuar como corpo assessor direto do Presidente da República, funçóes essas que foram fortalecidas no ano seguinte (1958) com o estabelecimento do Federal Council for Science and Technology. Estudando a influência exercida pelo ponto de vista dos tecnólogos na determinação das políticas governamentais, Gilpin chegou à conclusão de que "tôdas as principais diretrizes concernentes às armas nucleares, com apenas um única exceção, foram invariàvelmente concebidas por cientistas: apenas a doutrina da retaliação em massa teria tido uma origem distinta". ${ }^{12}$

Semelhantes evidências de tecnocratização podem ser interpretadas a partir de dois pontos de vista distintos. Quando examinadas em têrmos de volume de participação dos especialistas nas atividades levadas a cabo pelas agências governamentais, deparamos com um notável incremento dessa participação, bem como uma diversidade de novas posições organizacionais criadas precisamente com o propósito de torná-la mais efetiva. A aparência de tecnocratização daí resultante tende, no entanto, a se dissolver com surpreendente rapidez na medida em que examinamos o mesmo fenômeno, do ponto de vista dos centros de decisão. Por que, por exemplo, não interpretar as mudanças ocorridas na composição do Partido Comunista da União Soviética como manifestação do fortàlecimento das direções partidárias? Teriam essas direções se tornado mais poderosas, em comparação com a burocracia estatal, caso tivessem mantido inalterada a proporção de especialistas entre os membros do partido? Comentando êsse desenvolvimento, Fainsod ${ }^{13}$ sugere uma interpretação na linha antitecnocrática ao observar que, como fôrça dominante na sociedade soviética, o partido certamente seria incapaz de desincumbir-se de suas responsabilidades governamentais se não incorporasse às suas fileiras o estrato social emergente formado pelos representantes da nova intelligentsia técnica, administrativa e cultural. O mesmo tipo de raciocinio pode ser feito com relação ao poder executivo norteamericano. Os ocupantes das posições centrais, na medida em que passaram a dispor de maior apoio técnico-científico, sim-

12 GILPIN. American Scientists and Nuclear Weapons Policy. Princeton University Press, 1962.

13 Fanssod. How Russia is Ruled. Harvard University Press, 1963. 
plesmente aumentaram sua autonomia e seu poder de barganha nas negociações com os grupos de pressão, os partidos políticos, as comissóes de congresso, a diplomacia estrangeira ou qualquer outro interêsse organizado que participe da disputa política. O significado dessas afirmações ficará mais claro depois que tivermos examinado os aspectos a serem abordados no tópico seguinte.

3.3. Em matéria de análise política, dificilmente pode haver um equívoco mais ingênuo do que o da imagem que figura $o$ dirigente organizacional como um amador suscetivel de sentirse amedrontado e desnorteado diante de um simples relatório técnico, ao mesmo tempo em que se mostra incapaz de ter outro objetivo na vida que não seja o de fazer o jogo político de seus próprios assessôres. Nesse contexto, seria conveniente recordar alguns pontos usualmente negligenciados pelos ideólogos da tecnocracia.

Em primeiro lugar, vale a pena ter presente o que nos diz a literatura sôbre grupos de interêsse. A maior parte dos estudos realizados nessa área indica que as oportunidades de êxito na disputa por medidas políticas dependem, em grande parte, do contrôle que as agências governamentais e os diferentes grupos possam ter sôbre conhecimentos e informações julgadas relevantes para a fundamentação da decisão. $H$. Wilensky traduziu êsse estado de coisas na hipótese, segundo a qual, quanto mais uma organização está em conflito com o seu meio social ou depende dêle para materializar os seus objetivos centrais, tanto maior será a quantidade de recursos que ela investirá nas funções de inteligência. Se assim é, a corrida por mais e melhor saber especializado, tanto no setor da administração, quanto no setor da infra-estrutura política, explica-se não porque os interêsses em luta estejam sendo forçados a se desfigurar na submissão homogeneizadora ao domínio tecnocrático mas, muito ao contrário, porque visam a fortalecer suas condiçóes competitivas e maximizar suas probabilidades de êxito. Num contexto em que fôrças mùtuamente excludentes dispõem de assessorias próprias comparàvelmente competentes, indagar que lado é o do suposto poder tecnocrático, parece ser uma pergunta desprovida de interêsse. Como assinala Meynaud, a predisposição 
técnica de elevar a eficácia da ação se opõe à tendência para questionar as estruturas de autoridade vigentes e contribui decisivamente para consolidá-las, reforçando sua capacidade de decidir com acêrto. Um tecnocrata por nós recentemente entrevistado foi incisivo ao declarar: "De fato, nós temos uma enorme liberdade de ação; podemos fazer pràticamente tudo o que queremos, contanto que nossas energias estejam voltadas para servir melhor aos interêsses de quem nos paga".

O segundo ponto que é preciso ser levado em consideração, para avaliar-se até onde é verossímil a suposta impotência do dirigente político, diz respeito ao modo pelo qual êle manipula os processos de recrutamento e promoção. Implìcitamente, a ideologia tecnocrática tenta insinuar a idéia de que a estratificação da comunidade técnico-científica se faz exclusiva ou principalmente em têrmos do critério de competência. Não há dúvida de que essa forma de estratificação existe e funciona para os indivíduos que internalizaram mais profundamente os valôres específicos da comunidade. outro, entretanto, o ponto de vista do político e, para êle, o que importa não é tanto a posição dos especialistas nas hierarquias profissionais, mas, antes e acima de tudo, o grau de compatibilidade entre os seus propósitos e as crenças e filiações associativas que diferenciam os especialistas entre si. Na percepção do político, a comunidade técnicocientífica não se apresenta como um todo politicamente indiferenciado; ao contrário, e com tôda a razão, sua atenção se concentra sôbre as linhas que partem o conjunto em subconjuntos distintos entre si, em têrmos de agrupamentos e correntes de opinião. Ninguém ignora que, de fato, a comunidade se estrutura dessa forma e o político não só está a par dêsse dado como o utiliza a seu favor para evitar o mal da impotência diante da perícia. Para os postos-chave de assessoria não são selecionados os melhores dentre os melhores, mas os melhores dentre os correligionários. O critério que conta em primeiro lugar é o grau de parentesco ideológico e de grupo; o máximo de tolerância autopermitido vai até o ponto de incluir os profissionais que se definem em têrmos de neutralidade ou imparcialidade, uma vez que se sabe que um técnico neutro, enquanto tal, não oferece o perigo de se comportar como um tecnocrata cheio de opinióes adversas e ansioso por vê-las prevalecer. Nos governos 
mais sofisticados, como é o caso dos Estados Unidos, os dirigentes podem dar-se ao luxo de criar duas ou mais assessorias para o estudo de um mesmo assunto, cada uma delas identificada com um certo tipo de orientação. $O$ dirigente, a quem cabe, em última análise, o direito de opção, beneficia-se duplamente dessa tática: não só fica conhecendo as implicações técnicas pressupostas pela alternativa que endossa, como também é informado de como devem ser cientificamente avaliadas as alternativas divergentes da sua. A técnica dos dois discursos igualmente convincentes que, na Grécia antiga, era apenas uma escola de retórica inspirada na habilidade dos filosofos sofistas, tornou-se modernamente um requintado instrumento de poder a serviço dos executivos interessados em reafirmar as suas prerrogativas de autoridade derradeira, seja qual fôr a complexidade dos assuntos que venham a ser postos em discussão.

A pesquisa histórica, tanto aqui como em outros países, tem indicado que o contrôle sôbre o processo de recrutamento e desrecrutamento tem sido usado com extraordinário tirocínio para garantir a hegemonia das elites de poder. Os dois lados dêsse processo são claramente descritos no estudo feito por Robert Merton sôbre a situação da ciência na Alemanha nazista. Por um lado, a elite governamental foi capaz de eliminar das universidades, das instituições científicas, dos laboratórios industriais e dos orgãos técnicos do Estado todos aquêles que não se ajustavam aos critérios por ela politicamente definidos e impostos. Por outro lado, e ao mesmo tempo em que assim procedia, a liderança nazista foi capaz de ampliar e fortalecer os quadros técnicos e científicos de cujo esfôrço organizado resultou o alargamento da base tecnológica requerida para a consecução dos objetivos políticos do Estado alemão. Como enfatizou Hitler, numa afirmação que, tìpicamente, não confunde tecnoassessoria com tecnocracia, "nós seguiremos avante porque temos a vontade fanática de nos ajudarmos a nós mesmos e porque contamos com os engenheiros e inventores que proverão nossas necessidades". ${ }^{14}$

Há ainda um terceiro aspecto frequientemente negligenciado pelos que consideram inevitável a subordinação dos dirigentes po-

Merton. In: Barber. Sociology of Science. Free Press, 1962. 
líticos aos peritos em assuntos altamente especializados. A ideologia tecnocrática difunde a falsa suposição de que os pareceres técnicos constituem a principal ou mesmo a única fonte de informação em que se baseiam as decisões organizacionais. De fato, uma boa parte das comunicaçóes que alimentam os processos decisórios emana das equipes especializadas encarregadas de estudar os problemas em discussão. Mas o que nem sempre é lembrado com a devida ênfase é que, a importância de tais equipes é extraordinàriamente minimizada pelo fato de haver, simultâneamente, outros cérebros igualmente aplicados ao mesmo estudo, sendo que êsses nada têm a ver como os estudiosos pròpriamente ditos. $\mathrm{Na}$ verdade, conforme foi salientado por Wilensky, ${ }^{15}$ há pelo menos três tipos de agentes coletadores e municiadores de informação relevante. Existe, por um lado, o staff técnico-científico incumbido de prover "a inteligência técnica de ordem econômica, jurídica ou científica que ajuda o dirigente a elaborar os argumentos de que necessita para lidar com os elementos internos é externos à organização, para rechaçar ataques e competir por mercados, poder e prestígio com as organizações rivais". Nessa primeira categoria estaria o pessoal ocupado em pesquisa, planejamento, análise e avaliação, o que inclui desde economistas e estatísticos até engenheiros-industriais e os management consultants. A principal tarefa do especialista, que Wilensky chama de facts-and-figures man, diz respeito a dados, prognósticos e argumentos: "o que se espera dêle são respostas rápidas e simples a complicadas questôes técnicas, bem como julgamentos sôbre o poder e as intenções dos competidores e inimigos".

Além do staff técnico-científico, e exercendo funções políticas que fortalecem a posição da chefia e eliminam a possibilidade dela ser capturada por complots tecnocráticos, encontram-se disponíveis os dois outros tipos de assessor: o "especialista em co. municações internas" e o "homem-contato". O primeiro "provê a inteligência política e ideológica de que o dirigente necessita para manter sua autoridade. Ele transmite, aos de baixo, as políticas adotadas e informa, aos de cima, sôbre o estado de espírito e as opiniões dos subordinados". Sua principal habilidade é a de "mudar os pensamentos, os sentimentos e a conduta dos

is WILENSKY. Organizational Intelligence. Basic Books, 1967.

Julho/Setembro 1970 
membros por meio de persuasão e da manipulação. Ele é valorizado por suas aptidões em matéria de propaganda e trabalho de grupo, por sua capacidade de controlar reaçóes coletivas e por seu conhecimento a respeito das políticas e personalidades da organização empregadora". No essencial, espera-se que o encarregado das comunicaçóes internas seja capaz de consolidar o prestígio das direções executivas e facilitar o contrôle sôbre os subordinados, entre os quais se incluem naturalmente os mem. bros das equipes técnico-científicas.

O homem-contato, por sua vez, também contribui, a seu modo, para diminuir substancialmente a dependência dos executivos com respeito aos supostos tecnocratas. Ele ajuda o dirigente a formar opinião sôbre o que fazer na medida em que liga a organização com o que se passa no mundo exterior. $E$ valorizado pelo que sabe ou consegue descobrir a respeito da "topografia política e social que caracteriza a sociedade envolvente". Suas aptidóes para conduzir inquéritos confidenciais, consultas, negociaçóes e mediações permitem-lhe identificar no momento apropriado quem tem as informaçóes relevantes e por que meios elas podem ser obtidas.

Quando analisada em têrmos da prática política efetiva, vê-se que não passa de uma simples elucubração acadêmica a imagem que retrata o dirigente organizacional folheando pilhas de maçudos pareceres técnicos em busca dos elementos informativos que nortearão o rumo de suas decisões. $\mathrm{Na}$ realidade, as oportunidades de intervir e determinar o curso dos acontecimentos não são oferecidas aos homens de saber, mas sim aos que ocupam as posiçóes de poder, a partir das quais é possível organizar o trabalho de especialistas e combinar os seus resultados com os demais recursos que contribuem para viabilizar a ação. Não faltam evidências que tendem a comprovar a existência dessa diversificação de papéis entre os que produzem conhecimentos e os que estão aptos a usá-los em proveito próprio. Nos estudos que realizou durante a década passada, Nora Mitrani usou a expressão "tecnoburocrata" para distinguir tanto os tecnologos, quanto os tecnocratas, daqueles que simplesmente controlam o produto gerado por equipes técnicas, os quais, no presente arti- 
go, têm sido chamados de "dirigentes organizacionais". ${ }^{16} \mathrm{Na}$ amostra entrevistada por Mitrani, em constraste com os tecnólogos desprovidos de ambições de poder, delineou-se entre os "tecnoburocratas" uma acentuada tendência no sentido de atribuir ao conceito "técnico" uma acepção tão extraordinàriamente ampla que fazia desaparecer por completo qualquer distinção entre êsse conceito e o de "dirigente". As definições formuladas pelos entrevistados foram do seguinte teor: "o técnico é aquêle que tem o espírito de sintese"; "é uma espécie de arquiteto do mundo"; "o técnico é aquêle que organiza". Um dos tecnoburocratas foi mais longe, não hesitando em definir mais claramente o que os outros estavam querendo dizer com tais expressões. $O$ técnico, disse êle, é o homem especializado que tem uma competência aguda sôbre um problema estreito. "Eu sou levado a reagir contra essa acepção demasiado restrita pois existe também o técnico em idéias gerais. Se um grande chefe é inteligente, êle pode dispensar a tecnicidade; eu próprio não me sinto um técnico, pois tenho um espírito bastante aberto; o chefe de orquestra que coordena os técnicos não é mais um técnico êle próprio". A mesma percepção da diferença entre as funções de comando e de assessoria técnica manifestou-se nas lacunas apontadas pelos entrevistados com respeito ao treinamento que receberam nas escolas; os tecnoburocratas queixaram-se de não ter aprendido o suficiente sôbre a "arte de comandar", "a arte de se tornar um chefe" e de não terem desenvolvido "aptidóes polivalentes".

Em um outro estudo, a propósito da constituição do Euratom, Nora Mitrani chegou a uma conclusão plenamente consistente com as indicações anteriores ao verificar que aquêle que não é capaz de coordenar um brain-trust de especialistas, "mesmo sendo um sábio de reputação mundial, se condena a permanecer um simples subalterno, sem dúvida temido, admirado e cortejado pelos governos mas, não obstante, dirigido e comandado $\mathrm{e}$, por fim, desacreditado, se passa a ser considerado indesejável". O modo pelo qual se processou a constituição do Euratom revelou que "muito antes que os cientistas, os especialistas e os experts tivessem qualquer oportunidade de manifestar suas tendencias

16 Mitrani. Attitudes et Symboles Techno-bureaucratiques. Cahiers Internationaux de Sociologie, vol. XXIV, 1958. 
tecnocráticas, êles foram explorados e suplantados pelos agrupamentos tecnoburocráticos formados por políticos, industriais e delegados sindicais".

3.4. A última questão que desejamos abordar neste artigo diz respeito às bases sociais da intervenção tecnocrática. A idéia de um poder tecnocrático, para fazer sentido, necessita pressupor a existência mais ou menos autônoma de um agrupamento social específico, caracterizado por um conjunto próprio de interêsses e aspiraçóes que o diferencia de outros setores da população e unifica a ação de seus representantes no plano polítitico em tôrno de orientaçóes ideológicas e objetivos programáticos comuns. Dada essa condição, seria possível dizer que a dominação tecnocrática abre efetivamente uma nova perspectiva política e significa uma alternativa a outras formas possiveis de dominação. Nesse caso, o poder exercido pelos tecnocratas estaria referido a uma base social diferenciada e dotada de direção própria e, assim sendo, tenderia a expressar interêsses objetivamente constituídos em oposição aos de outras categorias sociais igualmente empenhadas em estabelecer sua hegemonia sôbre o conjunto da sociedade.

Admitindo-se que a vida política diga respeito à distribuição de vantagens e desvantagens que atingem diferencialmente os diversos setores da estrutura social, caberia perguntar qual o sentido político das decisões tecnocráticas: são tomadas contra quem? Em nome de quem? Dizer-se que são tomadas contra a ignorância, o êrro e a incompetência, em nome da razão e do saber, é uma resposta que nada tem a ver com o que foi perguntado. $O$ que importa saber é se o tecnocrata atua responsàvelmente como representante de uma comunidade de interêsses suscetíveis de serem objeto de formulação consciente e organização política eficaz.

A literatura registra dois tipos distintos de resposta a essa indagação. A resposta sugerida pela sociologia das profissóes vai numa direção, ao passo que a dos analistas políticos toma a direção oposta. Com efeito, os estudos sôbre os aspectos não políticos do comportamento profissional, em contraste com os que focalizam as dimensóes pròpriamente políticas, apresentam um amplo consenso quanto à idéia de que os homens de saber devem 
ser visualizados em têrmos de uma unidade coletiva. Expressões tais como a comunidade profissional parecem sumarizar a noção predominante de que os membros dessa categoria pertencem a um todo social inclusivo e vivem em seu próprio mundo, relativamente segregados de outras esferas da vida social por fronteiras bem delineadas no interior das quais as fôrças centrípetas de unidade e coesão mais do que contrabalançam os efeitos dispersivos das fôrças desintegradoras. No estudo sugestivamente intitulado 0 Sistema Social da Ciência, ${ }^{17}$ o argumento básico de Norman Storer salienta precisamente êsse ponto: "devemos encarar a ciência como uma estrutura social um complexo de status e posições sociais cujas relaçóes particulares são reconhecidamente independentes de outras relações na sociedade. Devemos considerar a ciência como uma entidade auto-sustentada, um subsistema da sociedade".

A diferença específica do comportamento profissional tem sido destacada em uma série de aspectos. Dos membros da comunidade profissional, em contraste com os outsiders, espera-se um elevado grau de comprometimento com as tarefas e interêsses relacionados à meta do avanço sistemático do conhecimento e sua aplicação a situaçóes concretas em nome da melhoria das condiçóes que afetam a existência humana. Espera-se, igualmente, que as pessoas altamente profissionalizadas tenham em comum um elevado grande autocrontrôle e isenção subjetiva em sua conduta, atributos êsses que se apóiam em códigos de ética internalizados durante 0 processo de socialização profissional. Supõe-se, ademais, que essas pessoas se orientem por um sistema de recompensas primàriamente baseado em símbolos de work achievement, cujo significado é internamente elaborado pela comunidade profissional, não podendo, portanto, ser plenamente captado pelas pessoas que não se acham envolvidas no sistema de interações que individualiza a vida profissional. Admite-se, ainda, que a alocação de prestígio e estima social é canalizada principalmente para indivíduos e instituiçőes que se tornam proeminentes em função de suas performances no que diz respeito à manutenção e ao aperfeiçoamento dos padrões de excelência ética e técnica e que servem, por isso mesmo, de papéis-modêlo para os principiantes e candidatos a membro da

1t Storer. The Social System of Science. Free Press, 1967. 
comunidade. Supõe-se, finalmente, que a profissionalização leva os indivíduos a manifestar, em suas relações com as entidades empregadoras, uma insopitável preferência pelo padrão de contrôle interpares, em contraste com o padrão superordenado característico das relaçóes de autoridade nos contextos organizacionais.

A identificação dêsses e de outros traços definidores de uma subcultura relativamente autônoma, levou muitos autores a supor que estava dada uma base social suficientemente consolidada e apta a gerar os estímulos conduzentes à participação política com sentido coletivo, guiada por um sistema unidirecional de orientações com respeito aos diferentes objetos políticos. Imaginou-se, e muitos ainda imaginam, que os atributos culturais que fecham o sistema social técnico-científico às influências externas provenientes do meio seriam tão protetores contra a heteronomia no plano político, quanto pareciam sê-lo no plano social.

Não obstante, as evidencias empíricas disponíveis tendem a substanciar justamente a hipótese oposta, ou seja, de que naquilo que tem de aberto ao mundo exterior, o chamado sistema social da ciência é permeado pelas mais contraditórias influências políticas que o tornam irremediàvelmente fragmentado e dividido contra si mesmo, incapazes de agregar os diferentes interêsses setoriais num mesmo movimento de ação política unitária. Nesse sentido, vale a pena lembrar a conclusão a que chegou Bernard Barber, à guisa de generalização a partir dos dados existentes. "Nas sociedades modernas", diz êle, "parece não haver qualquer movimento, formal ou informal, de integração das profissões em um único grupo de poder. As diversas profissões frequientemente competem entre si. Elas também diferem quanto a uma variedade de questőes sociais nas quais sua própria competição não se encontra diretamente envolvida". ${ }^{18}$ Utilizando dados de outra natureza, Meynaud enfatiza o mesmo ponto ao sugerir que um dos principais obstáculos à influência tecnocrática decorre precisamente das divisóes que se configuram entre os próprios técnicos, as quais se expressam não só em têrmos de conflitos interdisciplinares, como também sob a forma de

18 BARBER. Some Problems in Sociology of the Professions. In: LYNN. The Professions in America. 
lutas intergeracionais e disputas por prestígios entre indivíduos e grupos de opinião.

Na verdade, não há dúvida de que não faltam dados sugerindo com certa clareza a probabilidade de que os profissionais tenham uma maior propensão a participar da vida política do que os demais setores da população. Essa hipótese tem sido indiretamente confirmada por uma série de estudos sôbre comportamento politico, graças aos quais se estabeleceu, com relativa firmeza, a existência de uma forte associação entre nivel educacional e participação política. Tais estudos têm insistido sôbre o fato de que a educação formal tende a expandir, de várias maneiras, a capacidade política dos indivíduos a ela expostos, em particular porque, nas sociedades modernas, é principalmente através da experiência escolar que os indivíduos adquirem, não só o treinamento e as habilidades socialmente requeridas para lograr um certo nível de participação efetiva, como também, a componente racional-secular do sistema de crenças e os sentimentos e motivações básicas que dão sentido e tornam apetecida a intervenção ativa no processo político. As evidências analisadas por Key, por exemplo, levaram-no a concluir que "altos níveis de participação política, um alto senso de eficácia pessoal e um alto senso de dever cívico ocorrem de modo extraordinàriamente mais freqüente entre pessoas com treinamento universitário do que entre aquelas cuja formação profissional se completou no nível elementar".18 Almond e Verba chegaram a idêntico resultado na análise dos dados coletados em cinco países diferentes. Segundo êsses autores, "não existe nenhuma outra variável que possa ser comparada (em têrmos de efeito demográfico) à variável educacional no que diz respeito à determinação de atitudes políticas. $O$ homem não-educado ou com limitada educação é um ator político diferente do homem que atingiu níveis superiores de educação". ${ }^{20}$ No entanto, a situação muda inteiramente de figura quando a questão é deslocada do grau para o conteúdo da participação. Ao contrário do que a ideologia tecnocrática presume, não parece haver indícios de um padrão diferenciado e internamente consistente que tipifi-

10 KeY, V. O. Public Opinion and American Democracy. Alfred A. Knopp, 1961 .

20 Almond e Verba. The Civic Culture. Little Brown, 1965. 
que uma orientação política comum, predominante entre os membros dos estratos profissionalizados. A noção mannheimiana de uma intelligentsia dotada de um ponto de vista próprio (porque descomprometida por igual com os diferentes interêsses materiais que se entrechocam na arena política) tende a ceder lugar - quando se toma em conta os resultados das pesquisas disponíveis - à idéia de uma multiplicidade de intelligentsias rivais, vinculadas, por laços de parentesco ideológico ou de grupo, há tantos quantos sejam os interêsses tangíveis ou intangiveis em que se divide a sociedade em questão.

Com efeito, ao fazer a avaliação dos dados referentes à relação, entre educação e envolvimento político, James Coleman constatou que "em muitas questões cruciais, os dados são inclusivos e contraditórios (...) Os achados dos estudos mais recentes in. dicam que a influência da educação sôbre as atividades políticas é mais complicada, incerta e variável do que originalmente se supunha". ${ }^{21}$ :que as informações existentes confirmam é, antes a inexistência de qualquer relação significativa entre grau de educação formal e direção do comportamento político. A variável educacional, conforme salienta Coleman, "pode reforçar ou debilitar preconceitos, conduzir ao radicalismo tanto quanto ao conservadorismo, e, certamente, não garante a racionalidade das orientações e do comportamento político". Por sua vez, as evidências recolhidas por Almond e Verba deram lugar à mesma conclusão: "o indivíduo educado se encontra, num certo sentido, disponível para a participação política. A educação, contudo, não determina o conteúdo dessa participação".

Para se ter uma idéia de quão incerta e variável pode ser a reação dos especialistas quando expostos a estímulos de ordem política, seria interessante discutir, ainda que sumàriamente, os resultados recentemente encontrados por Daniel Lerner e Albert Teich num survey sôbre as atitudes politicas dos cientistas europeus associados ao CERN (Organização Européia para Pesquisa Nuclear). Em aparente contradição com as idéias acima sustentadas, Lerner e Teich descobriram um elevado grau de convergência entre as orientações políticas dos entrevistados:

21 Coleman. Education and Political Development. Princeton University
Press, 1965. 
"a auto-identificação dos cientistas no espectro político esquerda-direita evidenciou uma tendência muito clara no sentido da esquerda. Virtualmente, todos os interrogados declararam ter um ponto de vista muito mais de esquerda do que de direita". ${ }^{22}$

A primeira dificuldade que surge para a interpretação dêsse aparente monolitismo reside no fato de que semelhante resultado é inconsistente com os elementos antidemocráticos que, em geral, se atribui à mentalidade tecnocrática, conforme foi salientado nas páginas anteriores em que foram discutidos os pontos de vista de Santos e Lamounier. Com efeito, se existisse uma orientação de esquerda tão majoritàriamente predominante, isso não só invalidaria os resultados estabelecidos em outras pesquisas (Mitrani, Meynaud, etc.) como, ademais, solaparia o próprio princípio de legitimação dos sistemas de fachada tecnocrática, fundados na supremacia forçosa da "razão competente". As propriedades que os entrevistados associam à posição de esquerda incluíam: idealismo, generosidade, objetividade e otimismo. Nas palavras de um dêles, "existem dois tipos de pessoas: os de esquerda pensam que a coisa mais importante é a generosidade das pessoas; os de direita, por sua vez, pensam que é o poder". Fôsse essa a orientação efetivamente predominante, e não apenas uma entre outras igualmente prováveis, seria particularmente difícil explicar a participação maciça e integrada dos tecnólogos como assessôres de governos autoritários (de direita ou de esquerda), sem falar dos que se identificam com os processos antidemocráticos em nome de suas próprias pretensões tecnocráticas.

$\mathrm{Na}$ verdade, todavia, quando examinado em maior minúcia, o consenso encontrado por Lerner e Teich se mostra muito mais frágil e superficial do que à primeira vista parecia ser. A aparente unidade de um bloco de opinião unidirecionado pode, de fato, fragmentar-se em uma multiplicidade de orientaçбes contrastantes quando se desce ao nível menos abstrato das disputas entre os grupos organizados para a ação política. Como assinalaram Lerner e Teich, "a predominância de sentimentos de esquerda é o resultado de uma orientação geral com respeito aos problemas sociais e não a escolha de uma linha política

22 LeRner e TeICH. Internationalism and World Politics Among CERN Scientists. Science and Public Affairs, fev. 1970. 
ou de uma ideologia econômica de preferência a outras. A noção de ideologia - com sua implicação de posições rìgidamente codificadas quanto a uma variedade de questões específicas foi redondamente rejeitada pela maioria dos cientistas. (...) Eles preferem abordar os problemas políticos de um modo genèricamente pragmático, conciliador e voltado para a resolução de problemas".

Como se vê, trata-se de um grupo de pessoas imbuídas de um forte senso de realidade e aptas a trabalhar, com igual eficiência, em qualquer variedade de contexto político. Não é por acaso que um outro traço marcante de suas convicções políticas reside na recusa que manifestaram de se identificar com qualquer partido ou movimento político existente ou por existir. O caráter potencialmente multifacético e, por isso mesmo, dòcilmente manipulável da cultura política característica dos meios técnico-científicos encontra sua expressão mais fidedigna nesse espírito de independência que não diz seu nome, nem se importa de ser confundido com suspensão do juízo e estado de disponibilidade.

Por falta de tecnocratas, até onde se sabe, nenhum govêrno morreu ou morrerá à míngua. Sejam quais forem os objetivos perseguidos pela elite governamental, sejam quais forem os meios que ela julgue conveniente empregar para a consecução do que tem em mira, sempre existe, na quantidade e na qualidade desejada, uma oferta satisfatória de especialistas ansiosos por construir com suas próprias mãos a fachada tecnocrática que a elite governamental deseja exibir aos olhos do grande público. Tanto a sucessão de regimes ao longo da história, quanto a variedade dos que atualmente se encontram em funcionamento, sugerem que a assim chamada comunidade técnico-científica tem sido surpreendentemente versátil em sua capacidade de abastecer o aparelho do Estado com os mais desencontrados tipos de vocação política e, ao mesmo tempo, sabidamente pouco imaginosa no que diz respeito à invenção de mecanismos de contrôle e prestação de contas que lhe permitissem não só exigir como obter um mínimo de comportamento responsável por parte de seus representantes nas estruturas de poder. 